\title{
ENERGY EFFICIENCY AND ALGORITHM FOR SELECTING DRIVES FOR TECHNOLOGICAL MACHINES
}

\author{
Andrenko Pavel ${ }^{1}$, Rogovyi Andrii ${ }^{2}$ \\ ${ }^{1}$ National Technical University Kharkiv Polytechnic Institute \\ ${ }^{2}$ Kharkiv National Automobile and Highway University
}

\begin{abstract}
Problem. The choice of the machine drive type at the design stage is a complex and multifaceted task, the correct solution of which largely depends on its technical level and operational qualities. The aim of the study is to identify the ways to increase the energy efficiency of technological machine drives and to develop an algorithm for selecting the drive type. Methodology. System analysis made it possible to analyze the environmental parameters in which it is appropriate to use a drive of one type or another, to develop criteria for comparing their application efficiency. The theory of automatic control methods made it possible to establish the drive characteristics. The theory of mechanisms and machines methods made it possible to determine the mass, size, and energy parameters of drives. Results. The main actions to improve the energy efficiency of technological machine drives are considered, an algorithm for choosing the drive type has been developed and a table has been created to compare the main consumer properties of drives. It has been established that the electrical drive of the executive elements is currently the main one in the area of mechatronic systems. It provides good control, easy feedback organization, high efficiency, and the best mass-dimensional efficiency. Originality. Considering the maximum number of factors, an algorithm for choosing the drive type has been developed. Criteria for comparing the efficiency of different drive types are proposed. Areas of effective application of electrical, hydraulic, pneumatic, and mechanical drives and their limiting output parameters are given. Practical value. Application of the developed algorithm reduces the time for selecting the drive type. In the future, it is necessary to supplement the existing database on the use of various drive types, based on the latest developments of their elements and circuit solutions, to develop new criteria for comparing drives of various types.
\end{abstract}

Key words: hydraulic drive, mechanical drive, comparison criterions, efficiency criterions, characteristics, mechanical drive.

\section{Introduction}

The intensification of drive systems operations and machine units, energy saving, improvement of working conditions forms the modern level and further development of technology [1-3]. Raising the technical level of machines requires increasing the energy efficiency and reliability of the drives used in them. The choice of the structure and drive type depends on the purpose of the machine, environmental conditions, the physical state of the object moved by the actuator, static, dynamic, and operational characteristics [4-6]. Choosing the optimal drive type is not a trivial task and requires the creation of an extensive database for multi-criteria assessment and reasoned decisionmaking [7-9].

\section{Analysis of publications}

Many scientific works are devoted to the calculation and design of drive systems [10-18]. They describe in detail the methods for calculating and choosing the main design parameters of various types of drives. In paper [14], effective areas of hydraulic, pneumatic, and electrical linear drive application are determined, the advantages and disadvantages of their use are described. In paper [15], a table comparing the characteristics of various linear drives is given, as well as a comparison of gearing systems used in conjunction with actuators (electrical cylinders). However, these papers do not give the characteristics of mechanical drives, do not consider the schemes of their connection with mechanical transmissions. In paper [16], a comparative analysis of the main indicators of hydraulic and pneumatic drives and the peculiarities of their use in mechatronic systems, a table of comparison of their indicators by various criteria is given. However, this paper does not consider the performance of electrical and mechanical drives. The paper [17] considers the actual problem of choosing the drive type for packaging equipment based on the comparative characteristics of electromechanical, pneumatic, hydraulic drives and their combinations in order to achieve a stepless change in rotational speed, linear motion and ensure complex motion laws of the machine parts. However, this article does not address mechanical drives. The criteria used to 
compare drives are selective. Article [18] is devoted to the development of a comprehensive universal criterion for assessing the technical level of hydraulic machines, hydraulic units, and hydraulic devices. It analyzes the existing single criteria by which one can compare hydraulic drives for various technological purposes. Some of the criteria in this article can be used when comparing different drive types. However, it lacks a comparison of different drive types.

Thus, we have not found any works that simultaneously consider electrical, hydraulic, pneumatic, and mechanical drives. The criteria for their comparison and the choice of the drive type, considering the energy source, environmental parameters, transported medium type, parameters and characteristics of the technological machine, have not been established. There are no universal criteria for their comparison. It should be noted that at the stage of schematics choosing of technological machine and drive for its implementation, there is a need to compare the consumer properties of various types drives. It also needs to identify effective areas of application, which allows improving the technical level, and therefore, competitiveness.

\section{The aim and problem statement}

The aim of this study is to develop the algorithm for choosing the drive type of technological machine and the table for comparing the main consumer properties of drives. To achieve this goal, it is necessary to analyze the environmental parameters, establish the limiting machine parameters, develop criteria for comparing the efficiency of using various types of drives.

\section{Application and parameter analysis of different drive types}

The electrical drive allows converting electrical energy directly into mechanical energy, has a high (up to $90 \%$ ) efficiency and high positioning accuracy (up to 8 microns with repeatability of at least 1 micron). It can be easily configured to control motion parameters, to control speed, position, moment of force application, diagnostics in real-time. Electrical drives are quieter than hydraulic and pneumatic drives. There is no risk of environmental pollution. As a rule, they have an affordable energy source, provide the ability to transfer energy over long distances without loss, simplicity of installation and maintenance, and stable operation over a wide temperature range. All this led to their widespread distribution. Recently, electrical cylinders (actuators) have been used to convert the rotation of the motor shaft into linear motion. They use a roller screw, ball screw, or screw-nut transmission [15]. The disadvantages of electrical drives include the fact that they are not used in explosive areas, magnetic fields, high levels of radiation, and high humidity. They are large in size. During their operation, overheating and wear of the gearbox occurs.

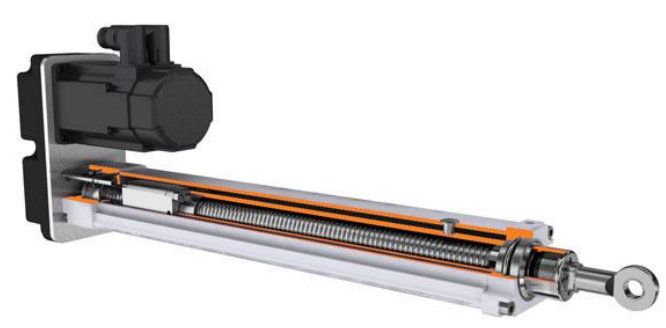

a

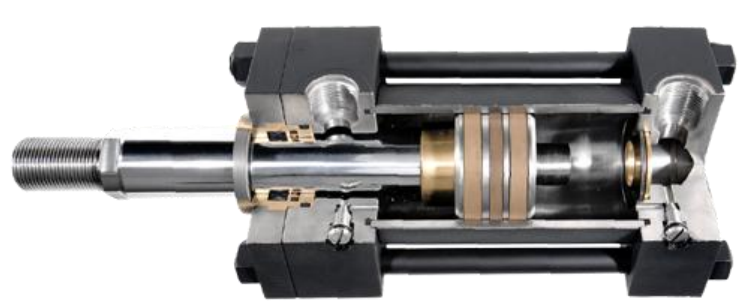

b
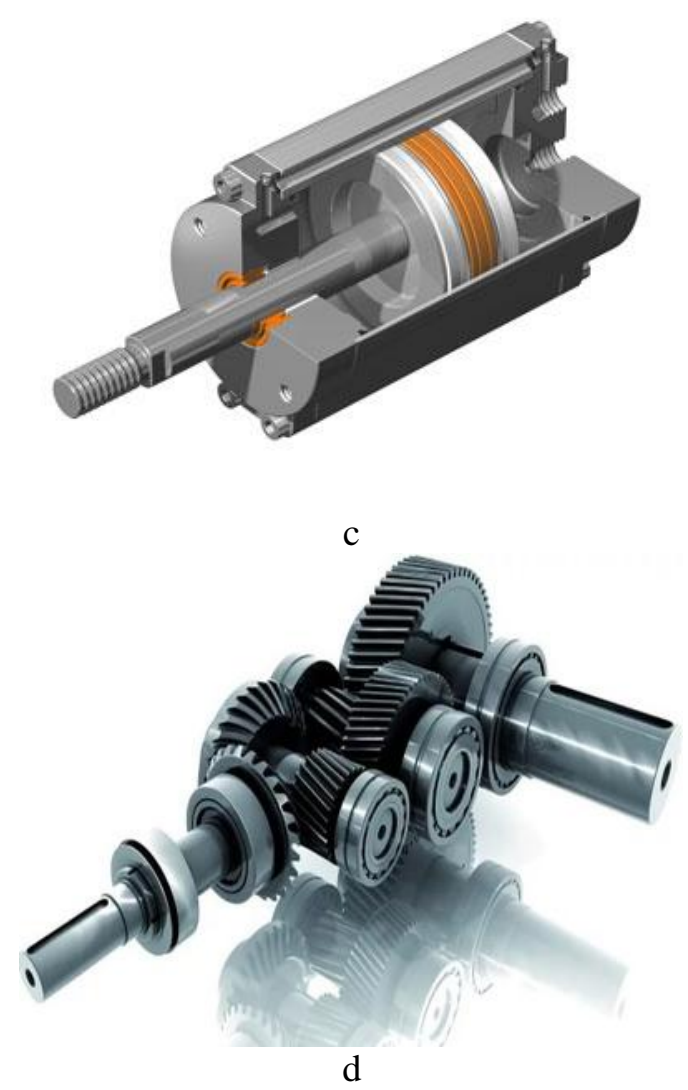

Fig. 1. Drives of technological machines [19]: a linear electrical drive; $b$ - hydraulic drive (drive cylinder); c - pneumatic drive (drive cylinder); $\mathrm{d}$ - mechanical drive (gearing) 
Hydraulic drives provide high positioning accuracy as the hydraulic fluid is practically incompressible. They provide great efforts, have a high relative power per volume, have low inertia, easily change the motion direction, have low power losses along the length of the pipeline, are used in magnetic and radiation fields, and provide reliable operation at sufficiently high temperatures. Their use enables miniaturization and integration with electronics. The disadvantages of hydraulic drives include wear of sealing elements and leaks of the working fluid, fire hazard, heating of the working fluid due to energy losses, which in turn leads to a decrease in the liquid viscosity. Leakages of liquid lead to environmental pollution. Hydraulic drives have a complex maintenance system in which it is necessary to replace the working fluid with a new one, and it is also necessary to regularly check and replace all seals. Also, the disadvantages include the need to use lots of components (tank, engine, pump, valves, heat exchanger, etc.), big size, energy consumption during movement, and resting state.

One of the directions of modern mobile and construction equipment hydraulic systems is the use of hydraulic rotators with a very high (more than $5000 \mathrm{Nm}$ ) torque and very low (up to 10 rpm) rotational speeds. The advantages of such hydraulic systems are: the ability to create a drive without a gearbox; high starting torque; fast acceleration and stabilization of power parameters is carried out using simple damping devices [20]. The hydraulic rotator does not have an output shaft, it is structurally designed in such a way that it is connected to the shaft of the active working body of a hydraulic machine using a spline hole made in a male displacer (rotor) [21]. The use of hydraulic rotators instead of standard hydraulic motors allows reducing metal consumption and maintenance costs, increasing reliability and technical level.

Pneumatic drives have the following advantages: simplicity of design, sufficient positioning accuracy (up to $2.5 \mathrm{~mm}$ with repeatability within $0.25 \mathrm{~mm}$ ). They are used in magnetic and radiation fields, operate reliably at sufficiently high temperatures, are lightweight and provide miniaturization in integration with electronics, are easy to maintain, and have the ability to connect many consumers to a single energy source. The disadvantages of the pneumatic drive include low efficiency of $5 \ldots 30 \%$, compared to other drives. Compressibility of air makes pneumatic drives less efficient, they have low forces and motion speeds of the working body, are explosive, require careful air prepara- tion (filtration), high noise level, and do not provide a stable actuator speed, especially under variable load, have large size and weight, high noise level, reaching $95 \ldots 130 \mathrm{dBA}$. These drives consume energy while driving and at resting state. Note that when using hydraulic and pneumatic drives, the pressure levels in the system must be indicated.

Mechanical drive is a set of devices designed to transmit motion. It is located between a motor and a loading mechanism. Belts, chain, cylindrical and conical gear transmissions, worm, planetary, wave, screw-nut, etc. transmissions are used as motion transducers. transmission. The mechanical drive includes a motor, a transmission mechanism, a working machine and a coupling. Since the motor shaft rotational speeds and the machine drive shaft rotational speeds are, as a rule, equal to each other, a gearbox consisting of a set of mechanical transmissions is used for matching in a mechanical drive. One of the most common types of modern mechanical systems is a gearbox. Drive gearboxes in which worm gears are used (worm cylindrical, globoid, spiroid, worm-cylindrical and cylindrical-worm gears) are able to provide a high gear ratio at a low noise level but have low efficiency and resource. The advantage of mechanical drives is the simplicity of design and reliability in operation.

The mechanical drive disadvantage is their large sizes when the branching of the transmitted power. Among mechanical drives, gear motors are widely used, which provide the conversion of electrical energy into mechanical energy. The use of geared motors can significantly simplify and reduce the drive design cost, reduce their sizes, as well as reduce maintenance costs. They provide a change in torque (decrease or increase), which, in combination with the regulation of the electrical motor speed, allows them to be used in servosystems.

Planetary gearboxes have the highest efficiency and longer service life. The most widespread are gear motors of cylindrical and worm type. Gearboxes are expensive and complex in design. Their efficiency is 0.98 and does not depend on the gear ratio. They allow transmitting significant torque with virtually no loss, have high accuracy and work stably under uneven load, and have high reliability. The disadvantages of gearboxes include a small gear ratio at one stage.

Worm gearboxes with a larger gear ratio provide smoothness and self-braking. However, they have low efficiency and resource, in comparison with cylindrical, limited power up to $60 \mathrm{~kW}$. Their use under uneven loading is limited. 
Table 1

Comparison of different drive types characteristics

\begin{tabular}{|c|c|c|c|c|c|}
\hline \multirow{2}{*}{$\begin{array}{l}\text { Indi- } \\
\text { cator }\end{array}$} & \multirow{2}{*}{ Criterion } & \multicolumn{4}{|c|}{ Drive type } \\
\hline & & Electrical & Hydraulic & Pneumatic & Mechanical \\
\hline 1 & 2 & 3 & 4 & 5 & 6 \\
\hline \multirow{5}{*}{ 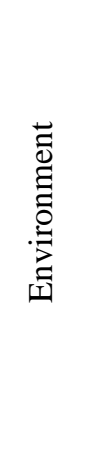 } & Radiation field & Not used & Does not effect & Does not effect & Affects strength \\
\hline & Magnetic field & Not used & Does not effect & Does not effect & \\
\hline & Temperature (standard range) & $-30 \ldots+70{ }^{\circ} \mathrm{C}$ & $-50 \ldots+100{ }^{\circ} \mathrm{C}$ & $-40 \ldots+120^{\circ} \mathrm{C}$ & $-50 \ldots+350{ }^{\circ} \mathrm{C}$ \\
\hline & Fire and explosion safety & $\begin{array}{c}\text { Not used in } \\
\text { high fire hazard conditions }\end{array}$ & Fire hazard & Explosive & fire and explosion safety \\
\hline & Leakages, dustiness & Does not effect & Contaminates & Does not effect & Contaminates \\
\hline \multirow{7}{*}{ 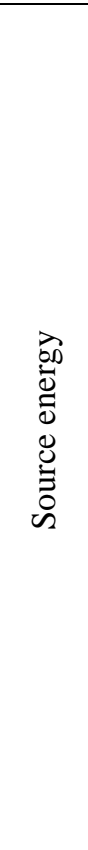 } & $\begin{array}{l}\text { Engine: } \\
\text { heat } \\
\text { electrical } \\
\text { pneumatic } \\
\text { hydraulic }\end{array}$ & $\begin{array}{l}\text { Not used } \\
\text { Used } \\
\text { Not used } \\
\text { Not used }\end{array}$ & $\begin{array}{l}\text { Not used } \\
\text { Pump drive } \\
\text { Not used } \\
\text { Not used }\end{array}$ & $\begin{array}{l}\text { Compressor drive } \\
\text { Used } \\
\text { Used }\end{array}$ & $\begin{array}{l}\text { Transmission drive } \\
\text { Transmission drive } \\
\text { Transmission drive }\end{array}$ \\
\hline & Working body & Electicity & $\begin{array}{l}\text { Mineral oils, emulsions, } \\
\text { aqueous solutions, special } \\
\text { liquids }\end{array}$ & Air & Mechanical transmissions \\
\hline & Power transmission devices & Electrical wire & Pipeline & Pipeline & $\begin{array}{c}\text { Transmissions: gear, } \\
\text { wave, belt, chain, friction }\end{array}$ \\
\hline & Energy storage & Accumulator & Hydraulic accumulator & Receiver & Spring \\
\hline & Power transmission & Long distances & $250 \ldots 300 \mathrm{~m}$ & Up to $1 \mathrm{~km}$ & Minor distance \\
\hline & $\begin{array}{l}\text { Power transmission rate (signal transmis- } \\
\text { sion) }\end{array}$ & Up to $300000 \mathrm{~km} / \mathrm{s}$ & $\mathrm{Up}$ to $1.4 \mathrm{~km} / \mathrm{s}$ & $\mathrm{Up}$ to $40 \mathrm{~m} / \mathrm{s}$ & Transmission dependent \\
\hline & $\begin{array}{l}\text { The main elements of } \\
\text { the power system }\end{array}$ & $\begin{array}{c}\text { Transformers, } \\
\text { Safety valves, equipment, } \\
\text { switches, electromagnets, } \\
\text { motors, devices }\end{array}$ & $\begin{array}{l}\text { Pump, tank, filters, distribu- } \\
\text { tion and control equipment, } \\
\text { actuators (energy consump- } \\
\text { tion during rest and motion) }\end{array}$ & $\begin{array}{l}\text { Compressor, receiver, air } \\
\text { conditioning devices, reduc- } \\
\text { er, control equipment, } \\
\text { pneumatic actuators }\end{array}$ & $\begin{array}{l}\text { Gearboxes, belt, chain, } \\
\text { gear, worm, wave, plane- } \\
\text { tary gear or screw-nut }\end{array}$ \\
\hline
\end{tabular}




\begin{tabular}{|c|c|c|c|c|c|}
\hline 1 & 2 & 3 & 4 & 5 & 6 \\
\hline \multirow{13}{*}{ 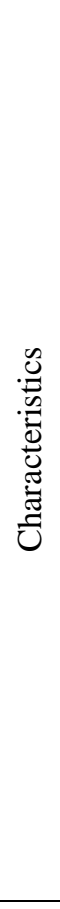 } & Movable body: & $\begin{array}{c}\text { Applicable } \\
\text { Applicable } \\
\text { Not applicable }\end{array}$ & $\begin{array}{l}\text { Applicable } \\
\text { Applicable } \\
\text { Applicable } \\
\end{array}$ & $\begin{array}{l}\text { Applicable } \\
\text { Applicable } \\
\text { Applicable } \\
\end{array}$ & $\begin{array}{l}\text { Applicable } \\
\text { Applicable } \\
\text { Applicable } \\
\end{array}$ \\
\hline & Motion direction: & $\begin{array}{l}\text { Electrical motor } \\
\text { Electrical cylinder }\end{array}$ & $\begin{array}{l}\text { Hydraulic motor } \\
\text { Hydraulic actuator }\end{array}$ & $\begin{array}{l}\text { Pneumatic motor } \\
\text { Pneumatic actuator }\end{array}$ & $\begin{array}{c}\text { Gearbox } \\
\text { Screw-nut }\end{array}$ \\
\hline & Actuator speed (max) & $\begin{array}{l}\text { Significant, depends on the } \\
\text { actuator }\end{array}$ & $1.0 \mathrm{~m} / \mathrm{s}$ & $1.5 \ldots 10 \mathrm{~m} / \mathrm{s}$ & $\begin{array}{l}\text { Significant, depends on the } \\
\text { actuator }\end{array}$ \\
\hline & Actuator load & Big & Up to $3000 \mathrm{kN}$ & Up to $120 \mathrm{kN}$ & Depends on the type \\
\hline & Continuous overload & Overcurrent is not allowed & Allowable & Allowable & Allowable \\
\hline & Power level & Up to $10^{5} \mathrm{~W}$ & Up to $10^{8} \mathrm{~W}$ & Up to $10^{5} \mathrm{~W}$ & Up to $10^{8} \mathrm{~W}$ \\
\hline & Output link speed regulation & Wide control range & Wide control range & $\begin{array}{l}\text { Sufficiently wide control } \\
\text { range }\end{array}$ & Wide control range \\
\hline & Positioning accuracy & $8 \mathrm{~mm}$ & $0.5 \mathrm{~mm}$ & $100 \mathrm{~mm}$ & \\
\hline & Stiffness & High & High & Low & High. Depends on the type \\
\hline & Efficiency & More than 0.9 & More than 0.9 & Up to 0.3 & More than 0.9 \\
\hline & Relative costs of energy saving & Low 1 & High $3 \ldots 5$ & Very high $7 \ldots 10$ & Low 1 \\
\hline & The cost & $\begin{array}{c}\text { Comparable to pneumatic } \\
\text { drive }\end{array}$ & $\begin{array}{l}\text { Above pneumatic and elec- } \\
\text { trical drive }\end{array}$ & & $\begin{array}{c}\text { Comparable to pneumatic } \\
\text { drive }\end{array}$ \\
\hline & Staff qualification & $\begin{array}{l}\text { Specialists with knowledge } \\
\text { of electronics required }\end{array}$ & $\begin{array}{c}\text { Lower than for servicing } \\
\text { electrical drives }\end{array}$ & $\begin{array}{c}\text { Lower than for servicing } \\
\text { electrical drives }\end{array}$ & $\begin{array}{c}\text { Lower than for servicing } \\
\text { electrical drives }\end{array}$ \\
\hline \multirow{9}{*}{ : } & \multicolumn{5}{|c|}{ Characteristic size $l$} \\
\hline & \multicolumn{5}{|c|}{ Overall dimension $L_{\Gamma}$} \\
\hline & \multicolumn{5}{|c|}{ Compactness factor $k_{W}=m / W$} \\
\hline & \multicolumn{5}{|c|}{ Energy intensity factor $k_{P}=P / W$} \\
\hline & \multicolumn{5}{|c|}{ Drive uptime probability $\tilde{P}(t)$} \\
\hline & \multicolumn{5}{|c|}{ Overload criterion $k_{e x t}=p_{\max } /\left(\left[n_{\sigma}\right] p_{\text {nom }}\right)$} \\
\hline & \multicolumn{5}{|c|}{ Quality factor of the drive $D_{f}=2 \pi f_{0} E / P_{\text {pos }}$} \\
\hline & \multicolumn{5}{|c|}{ Relative noise level $\bar{L}_{m d B A}=L_{m d B A} / L_{m 0 d B A}$} \\
\hline & \multicolumn{5}{|c|}{ Unification indicator $K_{\Pi}$} \\
\hline
\end{tabular}


The choice of the drive type is carried out in accordance with the requirements for the designed machine. In this regard, it is advisable to compare the characteristics of drives in terms of their performance. It should be noted that each of the drive types has a certain set of advantages and disadvantages. A qualitative assessment of the main indicators of drive types is given in the table. 1 [1-21].

The table uses the following notation: $m$ is the mass, $W$ is the volume that the hydraulic machine occupies; $P$ is the drive output power; $p_{\max }$ is the maximum load; $p_{\text {nom }}$ is the nominal load; $\left[n_{\sigma}\right]$ is the safety factor; $f_{0}$ is the resonant frequency of drive oscillations; $E$ is the energy stored by the oscillating drive system; $P_{p o s}$ is the dissipated power; $L_{m d B A}, L_{m 0 d B A}$ are respectively the basic noise level during the operation of the drive and the noise level in the design office.

\section{Drive type selection algorithm}

1. Consider the environmental conditions in which the drive operates (radiation, electrical, magnetic field, fire and explosion safety, temperature, leakage, dustiness (see Table 1). Exclude from consideration the drive type is not used in the conditions specified in the technical specifications for the development of a drive for a technological machine.

2. Analyze the presence of an energy source, devices for its storage and transmission, the power transmission distance, the main elements of the power system. According to Table 1, a power source is selected, which significantly affects the choice of the drive type.

3. The characteristics of the technological machine drive are considered. This point of the algorithm is carried out based on the terms of reference for the drive design. A preliminary design of drives is developed that can be used in the given environmental conditions with the selected type of power source. Special criteria are calculated and a comparison table of various drive types is compiled (criteria in Table 1), and it is analyzed. Consider the complexity of organizing feedback.

4. Analyze the parameters of the table. 1 for each criterion. Depending on their values, a number is assigned from one to four. The numbers obtained in each column are added together. The drive that will have the smallest amount and is rational, and will provide the conditions specified in the project.

To select the drive type, the method of independent expert evaluation, or the method of rank correlation can also be applied [22]. The essence of the method lies in the fact that a group of expert assesses is asked a number of questions concerning the structure and parameters of the projected drive. Each expert expresses his opinion on the basis of experience and knowledge. The forecast is determined by the appropriate processing of expert responses. In this case, the opinion of experts is interpreted as an intelligent statistical experiment. It is advisable to use this method to solve problems of forecasting development prospects, substantiating the development of new schemes and improving the drive parameters; determination of reliability indicators in conditions when the use of other methods is impossible due to the lack of a priori information.

\section{Key energy saving measures in drive systems}

A significant proportion of modern drive systems are electrically driven. Therefore, energy saving in an electrical drive has a significant impact on the energy saving of hydraulic, pneumatic, and mechanical drives. Thus, the main direction of energy saving in drive systems should be the transition from an unregulated electrical drive to a controlled one. Its use allows saving from 2 to $30 \%$ of electricity and eliminating the use of control valves, which leads not only to direct energy savings but also contributes to higher labor productivity and reduced wear and tear of mechanical equipment [23].

The main ways of energy saving in an electrical drive are:

- the use of energy-efficient engines that due to an increase in the mass of the active materials, their quality, as well as due to special design techniques, it is possible to increase the rated efficiency by $1 \ldots 5 \%$, by choosing a motor in order to comply with the rated thermal regime of the engine during operation;

- increasing the power supply frequency to $500 \ldots 1000 \mathrm{~Hz}$ and above;

- application of adjustable electric drives power modules with maximum efficiency and power;

- using braking resistors;

- reduction of losses in supply networks due to the use of switching capacitor banks, synchronous compensators, filter-compensating devices, etc.;

- the use of simple thyristor voltage regulators used for soft start and stop of the electrical drive; 
- use of adaptive control methods, elimination of intermediate transmissions;

- selection of operation rational modes, optimization of dynamic modes, use of energy accumulators; exclusion of idling.

The main ways of energy saving in the hydraulic drive are:

- the use of variable pumps, including those with pressure compensators; p/q control provides electronic control of pressure and flow in accordance with the requirement of a particular cycle transition, or LS control;

- use of multi-flow pumps with the possibility of individual unloading of sections or pumpaccumulator hydraulic drives, where the pump periodically charges the battery and unloads in pauses between recharge cycles;

- use of pressure compensators and energy recuperators; electrical feedback and electrohydraulic flow control;

- increasing the efficiency of hydraulic machines, optimizing circuit solutions, using the latest systems of proportional electrical control, replacing throttle control with machine control and using the principle of frequency control or a pump-accumulator hydraulic drive, various methods of energy recovery; integration of electronics into the hydraulic drive control loop;

- use of energy-efficient pump-accumulator drives and multipliers, which allow increasing the pressure up to $200 \ldots 500 \mathrm{MPa}$;

- equipping hydraulic systems with devices that ensure functioning in a closed circulation system of a working fluid - safety and anticavitation valves, a feed pump, a flushing valve, regulators for various functional purposes, hydraulic devices that prevent operation in the mode of the constant opening of the safety valves of the main lines [8];

- the use of a small piston mini-pump "Egide", the rotation of which is carried out directly from the electric motor located next to the drive;

- the use of proportional control systems, the use of unsprung pressure compensators in electro-hydraulic flow sharing drives with the theoretical efficiency is close to unity [8].

In pneumatic drives, high-quality compressed air preparation is a prerequisite for energy saving. With the centralized production of compressed air, energy savings can be achieved by using a soft start device for the drive electric motor of the compressor by including electronic air controllers in the pneumatic system, minimizing losses along the length and on local resistances, choosing a rational diameter of pipe- lines.

It is possible to increase the energy efficiency of pneumatic systems:

- by supplying air to individual consumers through a local pressure booster or by installing an individual compressor;

- by switching to local systems for the production of compressed air located directly in the divisions of the enterprise and by the rational choice of the layout of pneumatic devices, including the use of gravity and energy saving braking schemes;

- reducing the pressure level in the system or the pneumatic cylinder pressure of the idling, the use of an effective control scheme, including the use of vacuum and regulated power off;

- the use of an air engine with holding brakes during long periods of inactivity, energy recovery [24];

- wear and leakages minimizing; reducing the length of pneumatic lines, rational organization of the suction line, using as an energy saving device compressed air energy accumulator connected to the exhaust line of the pneumatic drive through a check valve, utilizing the heat removed from the compressed air, which increases efficiency.

In mechanical drives, energy savings can be achieved by reducing weight and friction. The materials of the friction pairs, in addition to the required high strength, must have good antifriction properties. To reduce the friction force, the clearances of friction pairs should provide sliding friction with the oil layer. For this, it is advisable to use vibration rolling, which reduces the friction force by $20 \ldots 30 \%$, and increases the tightness by $10 \ldots 18 \%$.

The main way of energy saving is to increase the efficiency of mechanical transmissions [25], equip mechanical drives with energy recovery devices, and efficient speed control systems.

\section{Conclusion}

As a result of theoretical studies, comparative characteristics of electrical, hydraulic, pneumatic, and mechanical drives, areas of their effective application are presented. The algorithm for choosing the drive type of a technological machine is proposed.

It has been found that the electrical drive is currently the main one in the mechatronic systems area. It provides good control, easy feedback organization, high efficiency, and the best weight and size efficiency.

The hydraulic drive is more complex and expensive than the pneumatic and electrical drive. 
However, in the power range up to $1 \mathrm{~kW}$, the hydraulic system has the best weight and size and can be successfully used in systems where it is necessary to obtain significant efforts of the actuators with high positioning accuracy.

The pneumatic drive is the simplest, rather reliable and the cheapest. However, it has a limited load capacity, up to $10-20 \mathrm{~kg}$ and is badly controlled.

A mechanical drive is comparable in cost to a pneumatic drive, has high efficiency, high reliability, and ease of maintenance. The complexity of its manufacture largely depends on the type of transmission.

The proposed algorithm for selecting the drive type allows considering the maximum number of factors, to reasonably select the system type, to ensure the optimal design and operating parameters of the designed technological machine. In the future, it is necessary to supplement the existing database on the use of various type drives, based on the latest developments of their elements and circuit solutions, to develop new criteria for comparing various type systems.

The main measures for energy saving in drive systems are considered.

\section{References}

1. Lawrence A., Thollander P., Andrei M., Karlsson M. Specific energy consumption/use (SEC) in energy management for improving energy efficiency in industry: Meaning, usage and differences. Energies, 2019. 12(2), pp. 247.

2. Sun K., Hong T. A framework for quantifying the impact of occupant behavior on energy savings of energy conservation measures. Energy and Buildings, 2017. 146, pp. 383-396.

3. Сьомін Д.О., Павлюченко В.О., Мальцев Я.І., Войцеховський С.В., Роговий А.С., Дмитріснко Л.В., Мальцева М.О. Вихрові виконавчі пристрої: у 2 ч.: монографія. Ч.1 Однорідні робочі середовища. 2009. 256 с.

4. Роговой А.С. Энергетическая эффективность пневмотранспортних установок. Вісник СНУ ім. В.Даля. 2016. № 1 (225). С. 189-196.

5. Андренко П.Н., Лурье 3.Я. Тенденции развития объемных гидроприводов. Промислова гідравліка і пневматика, 2013. № 3(41). С. 312.

6. Rogovyi A.S., Voronova Ye. Comparative Analysis Of Performance Characteristics Of Jet Vortex Type Superchargers. Автомобильный транспорт. 2016. Вып. 38. С. 93-98

7. Suzumori K., Faudzi A. A. Trends in hydraulic actuators and components in legged and tough robots: a review. Advanced Robotics, 2018. Vol. 32(9), pp. 458-476.

8. Андренко П.Н., Лурье 3.Я. Направления развития объемного гидропривода. Промислова гідравліка $і$ пневматика, 2016. № 2(52). C. 3-14.

9. Роговой А.С. Энергетическая эффективность гидротранспортных установок. Вестник ХНАДУ. 2017. Вып. 76. С. 96-103.

10. Свешников В.К. Станочные гидроприводы: Справочник. 6-е изд. перераб. и доп. СанктПетербург: Политехника, 2015. 627 с.

11. Bishop, Robert H., ed. The mechatronics handbook-2 volume set. CRC press, 2018.

12.Герц Е.В., Кудрявцев А.И., Ложкин О.В. Пневматические устройстна и системы в машиностроении: справочник. Москва: Машиностроение, 1981. 408 с.

13. Shetty Devdas, Richard A. Kolk. Mechatronics system design, SI version. Cengage Learning, 2010.

14. Абдрахманов А.А., Сафин Г.Г. Актуаторы как альтернатива гидро- и пневмопривода. Современная техника и технологии. 2016. № 12-2. C. 78-80.

15. Liu D., Wang J., Wang S., Shi D. Active disturbance rejection control for electric cylinders with PD-type event-triggering condition. Control Engineering Practice, 2020. Vol. 100. pp. 104448.

16. Сарваров А.С., Васильев А.Е., Даниленко К.В., Меньщикова Е.В. Сравнительный анализ приводов мехатронных систем. Теория u практика автоматизированного електропривода. ЭСиК. 2014. № 4(25). С. 2125.

17. Кривопляс-Володина Л.А., Гавва А.Н. Двигатель в упаковочной технике. Какой выбрать? Упаковка. 2016. № 1. С. 32-36.

18. Андренко П.М., Лебедєв А.Ю. Комплексний універсальний критерій оцінки технічного рівня гідравлічних машин, гідроагрегатів та гідравлічних пристроїв. Промислова гідравліка і пневматика. 2017. № 3(57). С. 312.

19. Разница между электрическими, пневматическими и гидравлическими линейными приводами. Инженерные решения. 2020. URL: https://engineering-

solutions.ru/motorcontrol/actuator_linear/ (дата звернення: 14.11.2020).

20. Панченко А.И., Волошина А.А., Обернихин Ю.П. Основные направления гидрофикации мобильной техники. Пращзі ТДАТУ. 2013. Вип. 13. Т. 6. С 3-19.

21. Панченко А.И., Волошина А.А., Панченко И.А. Методологические основы проектирования гидравлических вращателей планетарного типа. MOTROL. - Commission of Motorization and Energetics in Agriculture. 2014. Vol. 16. No 3. pp. 179-186.

22. Коваленко А.А., Роговой А.С., Сёмин Д.А. Основы научных исследований (планирование экспериментов): монография. Луганск: изд-во ВНУ им. В. Даля, 2010. 210 с.

23. Malinowski J., Hoyt W., Zwanziger P., Finley B. Motor and Drive-System Efficiency Regulations: 
Review of Regulations in the United States and Europe. in IEEE Industry Applications Magazine, 2017. Vol. 23(1), pp. 34-41.

24. Dindorf R., Takosoglu J., Woś P. Development of pneumatic control systems (Rozwój pneumatycznych systemów sterowania). No. M89. Wydawnictwo Politechniki Świętokrzyskiej, 2017. 135 p.

25. Иванов М.Н., Финогенов В.А. Детали машин: учебник. Москва: Юрайт, 2015. 408 с.

\section{References}

1. Lawrence A., Thollander P., Andrei M., Karlsson M. (2019) Specific energy consumption/use (SEC) in energy management for improving energy efficiency in industry: Meaning, usage and differences. Energies, 12(2), 247.

2. Sun K., Hong T. (2017) A framework for quantifying the impact of occupant behavior on energy savings of energy conservation measures. Energy and Buildings. 146, 383-396.

3. Syomin D.O., Pavluchenko V.O., Maltsev Ya.I., Voytsekhovskyi S.V., Rogovyi A.S., Dmitrienko D.V., Maltseva M.O. (2009) Vykhrovi vykonavchi prystroyi [Vortex actuators]: Monograph. Part1. Odnoridni robochi seredovyshcha. [Homogeneous working fluids]. 256 p. [in Ukrainian].

4. Rogovyi A.S. (2016) Energeticheskaya effektivnost' pnevmotransportnikh ustanovok. [Energy efficiency of pneumatic installations]. Visnyk SNU im. V.Dalya, 1(225), 189-196.

5. Andrenko P.N., Lurie Z.Ya. (2013) Tendentsii razvitiya ob"emnykh gidroprivodov [Trends in the development of volumetric hydraulic drives]. Promyslova hidravlika i pnevmatyka, 3(41). 3-12.

6. Rogovyi A.S., Voronova Ye. (2016) Comparative Analysis Of Performance Characteristics Of Jet Vortex Type Superchargers. Automobile transport. 38. 93-98.

7. Suzumori K., Faudzi A.A. (2018) Trends in hydraulic actuators and components in legged and tough robots: a review. Advanced Robotics. 32(9), 458-476.

8. Andrenko P.N., Lurie Z.Ya. (2016) Napravleniya razvitiya ob"emnogo gidroprivoda [Directions of the development of volumetric hydraulic drives]. Promyslova hidravlika i pnevmatyka, 2(52). 3-14.

9. Rogovyi A.S. (2017) Energeticheskaya effektivnost' gidrotransportnykh ustanovok [Energy efficiency of hydraulic transport units]. Bulletin of Kharkov National Automobile and Highway University. 76. 96-103.

10. Sveshnikov V.K. (2015) Stanochnye gidroprivody [Machine hydraulic drives]: Spravochnik. 6-e izd. pererab. i dop. Saint Petersburg Politekhnika, 627 p. [in Russian].

11. Bishop R.H., ed. (2018) The mechatronics handbook-2 volume set. CRC press.

12. Gerts E.V., Kudryavtsev A.I., Lozhkin O.V. (1981) Pnevmaticheskie ustroistna i sistemy v mashinostroenii [Pneumatic devices and systems in machine building]. Spravochnik. Moskow. 408 p. [in Russian]

13. Shetty Devdas, Richard A. Kolk (2010). Mechatronics system design, SI version. Cengage Learning. 504 p.

14. Abdrakhmanov A.A., Safin G.G. (2016) Aktuatory-kak al'ternativa gidro- i pnevmoprivodu [Actuators - as an alternative to hydraulic and pneumatic drives]. Sovremennaya tekhnika i tekhnologii, 12-2. 78-80.

15. Liu D., Wang J., Wang S., Shi D. (2020) Active disturbance rejection control for electric cylinders with PD-type event-triggering condition. Control Engineering Practice, 100. 104448.

16. Sarvarov A.S., Vasil'ev A.E., Danilenko K.V., Men'shchikova E.V. (2014) Sravnitel'nyi analiz privodov mekhatronnykh sistem. [Comparative analysis of drives of mechatronic systems] Teoriya $i$ praktika avtomatizirovannogo elektroprivoda. ESiK. 4(25). 21-25.

17. Krivoplyas-Volodina L.A., Gavva A.N. (2016) Dvigatel' V upakovochnoi tekhnike. Kakoi vybrat'? [The engine in packaging technology. Which to choose?] Upakovka, 1. 32-36.

18. Andrenko P.M., Lebedev A.Yu. (2017) Kompleksnyy universal'nyy kryteriy otsinky tekhnichnoho rivnya hidravlichnykh mashyn, hidroah-rehativ ta hidravlichnykh prystroyiv [Comprehensive universal criterion for assessing the technical level of hydraulic machines, hydraulic units and hydraulic devices]. Promyslova hidravlika i pnevmatyka. 3(57). 3-12. [in Ukrainian]

19. Raznitsa mezhdu elektricheskimi, pnevmaticheskimi i gidravlicheskimi lineinymi pri-vodami [The difference between electric, pneumatic and hydraulic linear actuators]. Inzhenernye resheniya. (2020). Retrived from: https://engineeringsolutions.ru/motorcontrol/actuator_linear/ (accessed: 14.11.2020). [in Russian]

20. Panchenko A.I., Voloshina A.A., Obernikhin Yu.P. (2013). Osnovnye napravleniya gidrofikatsii mobil'noi tekhniki [The main directions of hydrofication of mobile equipment]. Pratsi TDATU, 13(6).3-19. [in Russian]

21. Panchenko A.I., Voloshina A.A., Panchenko I.A. (2014) Metodologicheskie osnovy proektirovaniya gidravlicheskikh vrashchatelei planetarnogo tipa [Methodological foundations for the design of hydraulic rotators of planetary type]. MOTROL. 16 (3). 179-186. [in Russian]

22. Kovalenko A.A., Rogovyi A.S., Syomin D.O. (2010) Osnovy nauchnykh issledovanii (planirovanie eksperimentov) [Fundamentals of Scientific Research (Experiment Planning)]: monograph. Lugansk. VNU im. Dalya Publ. 210 p. [in Russian]

23. Malinowski J., Hoyt W., Zwanziger P., Finley B. (2017) Motor and Drive-System Efficiency Regulations: Review of Regulations in the United 
States and Europe. in IEEE Industry Applications Magazine, 23(1), 34-41.

24. Dindorf R., Takosoglu J., Woś P. (2017) Rozwój pneumatycznych systemów sterowania [Development of pneumatic control systems] No. M89. Wydawnictwo Politechniki Świętokrzyskiej, 135 p. [in Polish]

25. Ivanov M.N., Finogenov V.A. (2015) Detali mashin [Machine parts]. Uchebnik. Moscow. Yurait. 408 p. [in Russian]

Andrenko Pavel ${ }^{1}$, professor, Doct. of Science, Department of Machine Components and Mechatronic Systems, tel. +38-057-707-64-55,

e-mail: andrenko1947@gmail.com

Rogovyi Andrii ${ }^{2}$, professor, Doct. of Science, Theoretical Mechanics and Hydraulics Department, tel. +38-057-707-37-30, e-mail: asrogovoy@ukr.net ${ }^{1}$ National Technical University Kharkiv Polytechnic Institute, 2 Kyrpychova str., Kharkiv, 61002, Ukraine.

${ }^{2}$ Kharkiv National Automobile and Highway University, 25, Yaroslava Mudrogo str., Kharkiv, 61002, Ukraine.

Аннотация. С учетом максимального количества факторов разработань алгоритм выбора типа привода технологической машины и таблиияа для сравнения их основных потребительских свойств. Предложены критерии для сравнения эффективности применения приводов различных типов. Рассмотрены основные мероприятия по энергосбережению в системах приводов.

Ключевые слова: гидравлический привод, механический привод, сравнение приводов, критерии эффективности, характеристики, механический привод.

Андренко Павел Николаевич ${ }^{1}$, д.т.н., проф. кафедры деталей машин и мехатронных систем, тел. +38-057-707-64-55,

e-mail: andrenko1947@ gmail.com

Роговой Андрей Сергеевич ${ }^{2}$, д.т.н., проф. кафедры теоретической механики и гидравлики, тел. +38-057-707-37-30, e-mail: asrogovoy@ukr.net. ${ }^{1}$ Национальный технический университет «Харьковский политехнический институт», 61002,

Украина, г. Харьков, ул. Кирпичева, 2

${ }^{2}$ Харьковский национальный автомобильнодорожный университет, 61002, Украина, г. Харьков, ул. Ярослава Мудрого, 25

Енергоефективність та алгоритм вибору приводів технологічних машин

Анотація. Проблема. Вибір типу привода на стадії проектування машини є складним та багатогранним завданням, від правильного вирішення якого значною мірою залежить ї̈ техніч- ний рівень та експлуатаційні якості. Метою роботи є визначення шляхів покращення енергоефективності приводів технологічних машин та розробка алгоритму вибору типу приводу. Методологія. Системний аналіз дозволив провести аналіз параметрів довкілля, в яких доцільно використовувати привод того чи іншого типу, розробити критерії для порівняння ефективності їхнього застосування. Методи теорії автоматичного регулювання дозволили встановити характеристики приводів. Методи теорії механізмів $i$ машин дозволили визначити масогабаритні та енергетичні показники приводів. Результати. Розглянуто основні заходи щодо підвищення енергоефективності приводів технологічних машин, розроблено алгоритм вибору типу привода та створено таблицю для порівняння основних споживчих властивостей приводів. Установлено, щзо електричний привод виконавчих органів на сьогодні є основним у галузі мехатронних систем. Він забезпечує добре управління, легку організацію зворотного зв'язку, високий ККД, найкрашу масо-габаритну ефективність. Наукова новизна. 3 урахуванням максимальної кількості факторів розроблено алгоритм вибору типа привода. Запропоновано критерії для порівняння ефективності застосування приводів різних типів. Наведено ефективні області застосування електричного, гідравлічного, пневматичного та механічного приводів та їхні граничні вихідні параметри. Практична цінність. Застосування розробленого алгоритму скорочує час вибору типу привода. У подальшому слід доповнювати наявну базу даних щзодо використання приводів різних типів, спираючись на новітні розробки їхніх елементів та схемні рішення, розробляти нові критерії порівняння приводів різних типів.

Ключові слова: гідравлічний привод, механічний привод, порівняння приводів, критерії ефективності, характеристики, механічний привод.

Андренко Павло Миколайович ${ }^{1}$, д.т.н., проф. кафедри деталей машин та мехатронних систем, тел. +38-057-707-64-55,

e-mail: andrenko1947@gmail.com

Роговий Андрій Сергійович ${ }^{2}$, д.т.н., проф. кафедри теоретичної механіки та гідравліки, тел. +38-057-707-37-30,

e-mail: asrogovoy@ukr.net.

${ }^{1}$ Національний технічний університет «Харківський політехнічний інститут», 61002, Україна, м. Харків, вул. Кирпичова, 2

${ }^{2}$ Харківський національний автомобільнодорожній університет, 61002, Україна, м. Харків, вул. Ярослава Мудрого, 25. 